術前に診断された有茥性肝細胞癌の 1 切除例

\begin{tabular}{|c|c|c|c|c|}
\hline \multicolumn{5}{|c|}{ 島根医科大学第 2 外科 } \\
\hline 河野 & 仁志 & 古賀 & 俊六 & 谷浦 \\
\hline 林 & 貴史 & 八板 & 朗 & 中村 \\
\hline
\end{tabular}

\title{
A CASE REPORT OF PEDUNCULATED HEPATOCELLULAR CARCINOMA DIAGNOSED BEFORE SURGERY
}

\author{
Hitoshi KOHNO, Shunroku KOGA, Hiroyuki TANIURA, \\ Takafumi HAYASHI, Akira YAITA and Teruhisa NAKAMURA
}

Second Department of Surgery, Shimane Medical University

索引用語：有茎性肝細胞癌

はじめに

肝細胞癌の発育様式についてはまだ不明な点が多い が，大部分は肝内発育型であり肝外発育型の有茎性肝 細胞癌はごく少数が報告されているにすぎない1) 7). 有茥性肝細胞癌は頻度が少いこともあって術前診断は 困難といわれてきたが，最近の computed tomography (CT)，血管造影などの画像診断法の進歩によって 術前診断す比較的容易となってきた。最近, 画像診断 によって術前に診断しえた有茎性肝細胞癌の 1 切除例 を経験したので報告する。

\section{I. 症 例}

患者：75歳, 女性.

主訴：右中腹部腫瘤。

家族歴, 既往歴, 生活歷：特記すべきことなし。

現病歴：昭和56年 2 月より脐の右側に違和感があ り, 同年 5 月同部に超手拳大の腫瘤があるのに気つい た. 腫瘤には自発痛, 圧痛はなく左右への可動性があっ たという。このころから全身倦总感, 食思不振が出現 し, 同年 6 月 18 日, 右中腹部腫瘤の診断にて当科入院. 腫瘤に気づいてから入院するまでに腫瘤の大きさは不 変であったという。また，入院までの 1 年間に $3 \mathrm{~kg}$ の体 重隇少があった。

入院時現症 : 体格小. 眼䀫結膜蔶血 $(+)$, 眼球強膜 黄染(一). 腹部所見では脐の右側にびをん性の膨隆を 認め, 触診にて $12 \times 7 \mathrm{~cm}$ の綐に長い棈円形の腫瘤を触

$<1986$ 年 5 月 14 日受理 $>$ 別刷請求先：河野 仁志 于693 出雲市塩冶町 $89-1$ 島根医科大学第 2 外科
知した. 腫瘤は表面平滑, 弾性硬で拍動や波動はなく， 左右には可動性があったが上下方向にはなく，圧痛は なかった。

入院時検査成績：白血球増多と高度の貧血がみられ た. 肝機能に異常なく血中 $\alpha$-フェトプロテイン值は 5 $\mathrm{ng} / \mathrm{ml}$ 以下と正常であった（表 1 ).

食道・胃透視所見：幽門前庭部大弯側に右下方から の圧排像がみられる以外は異常なし。

腹部超音波検查所見: 右中腹部隀瘤は囊胞状であ

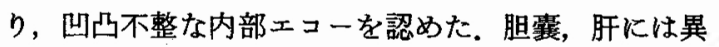
常なし。

腹部 CT 所見 : 右中腹部腫瘤に一致して肝右葉から

表 1 入院時検査成績

\begin{tabular}{lc}
\hline WBC & $14200 / \mathrm{mm}^{3}$ \\
RBC & $270 \times 10^{4} / \mathrm{mm}^{3}$ \\
Hb & $7.5 \mathrm{~g} / \mathrm{dl}$ \\
プロトロンビン時間 & $13.1 \mathrm{sec}$ \\
s-GOT & $14 \mathrm{IU} / \mathrm{L}$ \\
s-GPT & $12 \mathrm{IU} / \mathrm{L}$ \\
T.Bili. & $0.3 \mathrm{mg} / \mathrm{dl}$ \\
D.Bili. & $0.2 \mathrm{mg} / \mathrm{dl}$ \\
Al-p & $66 \mathrm{IU} / \mathrm{L}$ \\
$r$-GTP & $38 \mathrm{IU} / \mathrm{L}$ \\
S-Amy & $217 \mathrm{IU} / \mathrm{L}$ \\
LDH & $32 \mathrm{IU} / \mathrm{L}$ \\
ICG 停滞率(15') & $6.5 \%$ \\
AFP & $5 \mathrm{ng} / \quad 5 \mathrm{ng} / \mathrm{ml}$ 以下 \\
HBs-Ag & $(-)$ \\
CEA & $2.5 \mathrm{ng} / \mathrm{ml}$ 以下 \\
便潜血 & $(+)$ \\
\hline
\end{tabular}


因 $1 \mathrm{~A}$ 肝右葉に $3 \times 3 \mathrm{~cm}$ の low density area があ り，辺縁は比較的明瞭である。

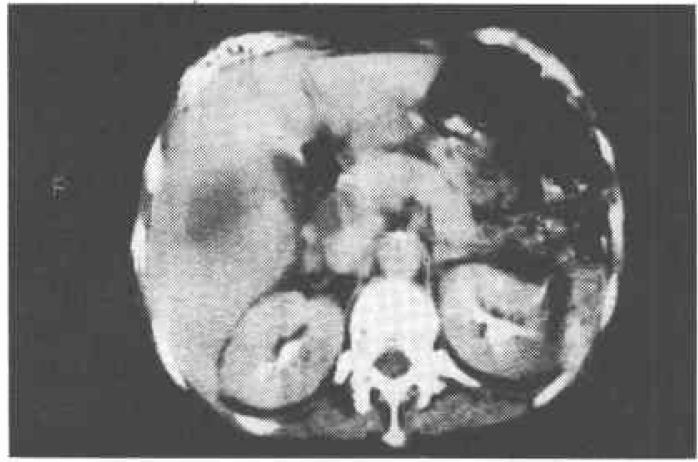

因 $1 \mathrm{~B}$ 図 $1 \mathrm{~A}$ の $1 \mathrm{~cm}$ 下部の $\mathrm{CT}$ 像. 腫瘤と肝との境 界は明膫で，腫湯内は不均質な density を示す。

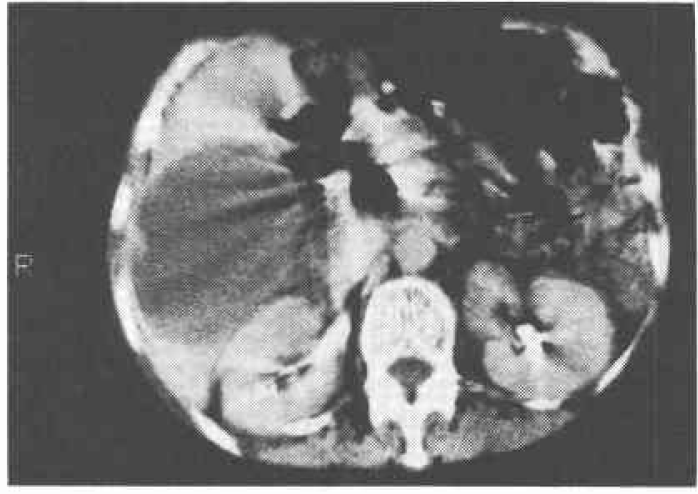

連続する low density areaを認める(図 1 A, B).

肝シンチグラム所見：肝右葉の側方下縁に不規則な 欠損像を認める。

腹腔動脈造影所見：右肝動脈前下行枝末梢に腫县血 管之腫場濃染像がみられる. 右胃大網動脈揖よび pancreatic arcadeより腫瘍壁に伸びる異常血管が新生さ れている（図 2 A, B).

以上の所見から，肝右葉下面より発生した肝外発育 型肝癌と診断し, 昭和56年 7 月 1 日開腹術を施行した。 手術所見：腹部正中切開にて開腹. 腫瘤は後腹膜の 前面で右側腹部を占めていた．図3に示すように肝右 葉下面に $5 \times 4 \mathrm{~cm}$ の起始部を有し，十二指腸，虫垂間

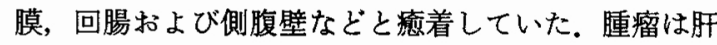
に近い部分では囊胞状で, 先端の部分は充実性であり, 生検では肝細胞癌であった。腫瘤以外の肝は正常で あった，以上の所見から腫瘤摘出術と肝動脈内乗管術 とを施行した。
図 $2 \mathrm{~A}$ 右肝動脈前下行枝末梢に stretch 像之腫湯血 管を認め右胃大網動脈よりの血管新生像も認められ る. (動脈相)

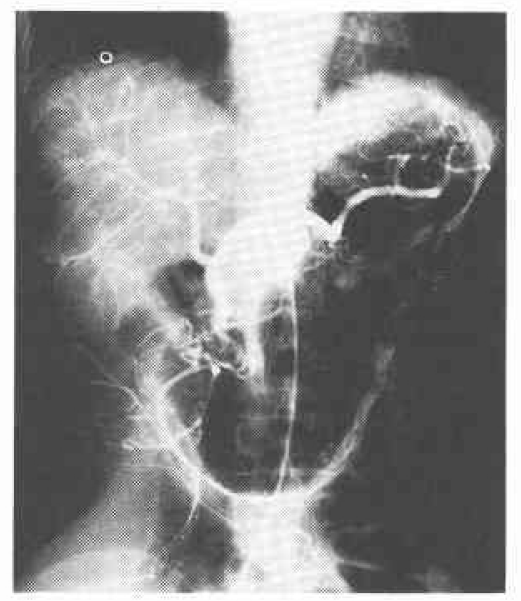

図 $2 \mathrm{~B}$ 右肝動脈前下行枝末梢に腫場濃染像を認める も, 腫瘍内の造影剤の pooling はほとんど認めない. (静脈相)

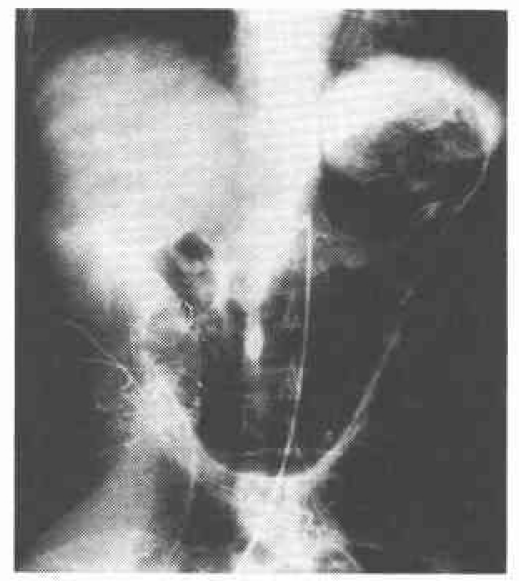

切除標本：腫瘤は図 4 のように $15 \times 9 \times 8 \mathrm{~cm}$ の腫瘤 と $9 \times 6 \times 4.5 \mathrm{~cm}$ の腫瘤が接着した逆ダルマ型で重さ は775gであった。肝に近い囊腫部分は壊死組織と古い 凝血塊を混じたコーヒー残査様の内容を有していた。 内容液の細胞診では class IV, $\alpha$-フェトプロテイン値 は $5 \mathrm{ng} / \mathrm{ml}$ 以下であった。一方, 先端部はぜい弱, 充実 性であった。

組織学的所見：Edmondson III 型肝細胞癌と診断さ れた（図 5).

術後経過：術後補助化学療法とし.て5-FU (250mg/ 日）を固有肝動脈より，術日から動注したが，悪心な 
図 3 手術所見（昭和56年 7 月 1 日）

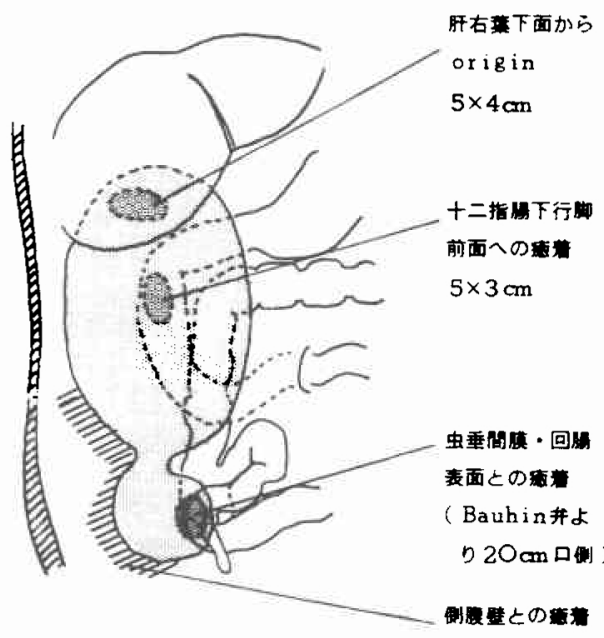

図 4 切除標本. ダルマ型の腫瘍を切離して示してい る. 上方は襄胞状，下方は充実性である.

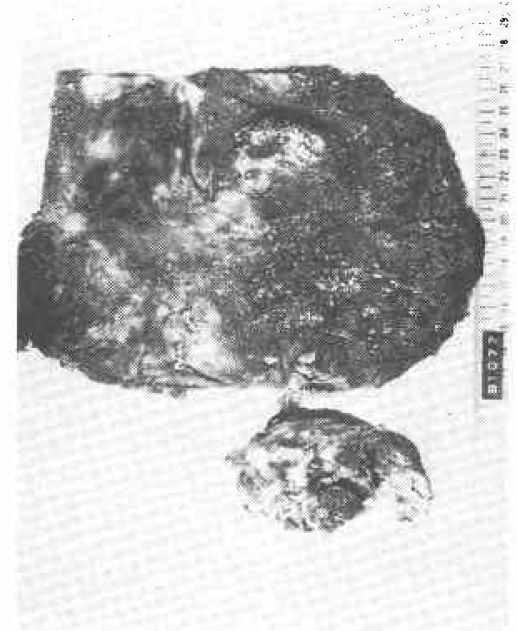

どの副作用のため 9 日目に中止した。術後28日目より 発黄し急性肝不全にて術後45日目に死亡した。剖検は 行っていない.

\section{II. 考 察}

有茎性肝細胞癌は Cristiani ${ }^{1}$ によって最初に報告さ れ，次いで Roux ${ }^{2)}$, Goldberg ら²の報告がみられる. その後外国では注とんど報告例はないようであり，本 症はま机な疾患と思われる。わが国では三好4)，行德"5, 佐々木 ${ }^{6)}$, 荒川防らの報告が認められる。

有茥性肝細胞癌の発生機序について行德ら5次の 3 つの発生母地を挙げている。第 1 は副肝葉からの発
図 5 Edmondson III 型の hepatocellular carcinoma. $(\times 250)$

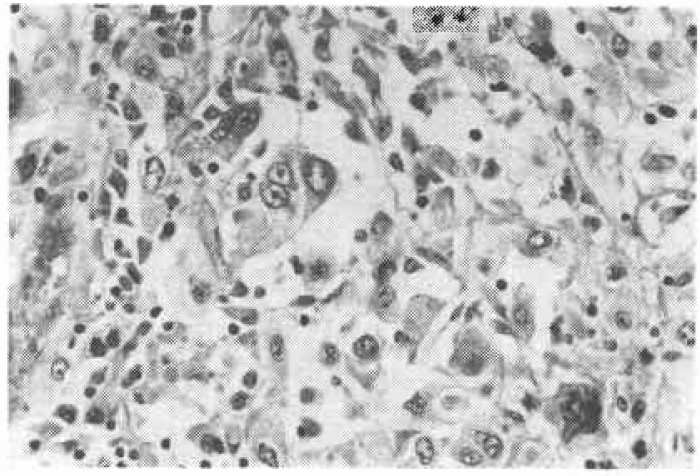

生であり，第 2 は異所性肝組織であり，第 3 の可能性 として肝硬変によって突出した結節の癌化である. 本 例では肝硬変の合併はみられず，また肝の本体とは結 合組織を介して右葉下面に連続していたことから，上 記の発生母地のうち副肝葉が右葉に存在し, 癌化, 肝 外性に発育したものと考克るのが妥当であるう。しか しながら，これらの発生母地からの癌化がすべて有茎 性発育を呈するといら確証はなく, 有茎性肝細胞癌の 発生機序にはまだ不明な点が多い。

有茎性肝細胞癌の術前診断については, かっては理 学的所見が主な診断根拠であり, 肝腫瘍のほかに腹部 腫瘤, 胆囊々腫などと診断されていた。しかし血管造 影が普及するに及んで肝腫瘍の確診が得られるように なり, さらに腹部 CT, 肝シンチグラフィー, 血中 $\alpha$ フェトプロテイン值などの総合的診断により巨大肝 focal nodular hyperplasia などとも区別され，肝細胞 癌の術前診断が得られるよらになった，本症例におい ても, 血中 $\alpha$ フェトプロテイン值は $5 \mathrm{ng} / \mathrm{ml}$ 以下と正 常であったが，腹部 CT にて肝と腫瘤に連続性を認め たこと, 動脈造影で腫湟栄養血管は右肝動脈前下行枝 でありその腫煌血管は遠心性の広がりを示さなかった こと, ${ }^{99 m} \mathrm{~T} \mathrm{c}$ 肝シンチグラフィーにて腫瘍は全く描出 されなかったこと，などょり有茥性肝細胞癌と診断し た.

有茎性肝細胞癌の切除率を佐々木 ${ }^{5}$, 荒川 ${ }^{8)}$ らが集録 した35例に本例を加えた36例についてみると，11例 (30.6\%)が切除されており，一般の肝細胞癌の切除率 $27.3 \%{ }^{8)}$ と添济同率である。しかしながら, 最近の画像 診断法の飛躍的進歩を考虑すると今後, 有荎性肝細胞 癌の切除率は一段と向上するものと期待される. 
本症例は術後早期から動注化学療法が行われたが肝 機能が悪化し急性肝不全で術後45日目に死亡した。肝 切除後の制癌化学療法については, 広範切除の場合は

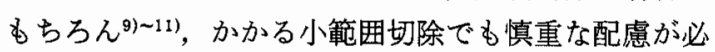
要と思われる。

\section{III. まとめ}

画像診断により術前に診断しえた有茥性肝細胞癌の 1 切除例を報告した。有茎性肝細胞癌の診断には血管 造影, 腹部 CT などの画像診断法が有力であり, 今後 切除適応となるものが増加するものと考觉られる。

\section{文 献}

1) Cristiani $\mathrm{H}$ : Des néoplasmes congênitaux. J del'anat et Physiol $27: 249-272,1891$

2) Roux: Un cas de cancer primitif du foie avec péricholécystite calculeuse, perforation in testinale. hémostase hépatique Rev méd de la Suisse Rom 17 : 114-119, 1897

3) Goldberg SJ, Wallenstein H: Primary massive liver cell carcinoma. Rev Gastroenterol 1 : 305-313, 1934

4) 三好正人, 岩佐 昇, 藤井浩注か: 肝外性汇発育 し腹腔内出血を括こした肝細胞癌の 1 例. 肝臓
$18: 765-771,1977$

5）行徳 豊, 杉原 甫, 尼崎辰彦泀か：有茎性肝細胞 癌の 1 剖検例。癌の臨 $26: 92-96,1980$

6）佐々木洋, 今岡真義, 松井征雄注か：肝外発育型肝 細胞癌の 1 例。日消外会誌 $14: 1236-1240,1981$

7) 荒川正博, 鹿毛政義, 磯村 正汪か：原発性肝癌の 病理形態学的研究一肝外に巨大な腫瘤を形成した いわゆる有茎性肝細胞癌 7 例の検討. 肝荿 23 : 942-948, 1982

8）日本肝癌研究会編：原発性肝癌に関する追跡調查 一第 5 報一。肝䁍 $23: 675-681,1982$

9) Nagasue N, Kobayashi $M$, Iwaki $A$ et al: Effect of 5 -fluorouracil on liver regeneration and metabolism after partial hepatectomy in the rat. Cancer $41: 435-443,1978$

10) Tanaka $Y$, Nagasue $N$, Kanashima $R$ et al: Effects of doxorubicin on liver regeneration and host survival after two-thirds hepatectomy in rats. Cancer $49: 19-24,1982$

11) Kohno $H$, Inokuchi $K$ : Effects of postoperative adjuvant chemotherapy on liver regeneration in partially hepatectomized rats. Jpn J Surg $14: 515-523,1984$ 